\title{
Eskrim Antrenörlerine Göre Eskrim Sporcularinin Performansını Etkileyen Psikolojik Faktörlerin Değerlendirilmesi: Nitel Çalışma
}

\author{
Naci KALKAN*1, Aylin ZEKİOĞLU ${ }^{1}$ \\ ${ }^{1}$ Manisa Celal Bayar Üniversitesi, Spor Bilimleri Fakültesi
}

$\ddot{\mathbf{O z}}$

Orijinal Makale

$\mathrm{Bu}$ çalışma, eskrim sporcularının performanslarını etkileyen psikolojik faktörlerin neler olduğunu ölçmek amacıyla tasarlanmıştır. Çalışmada, nitel araştırma yöntemlerinden durum çalışması deseni kullanılmıştır. Örneklem yöntemi, amaçlı örnekleme yöntemlerinden kolay ulaşılabilir durum örneklemesidir. Örneklem grubu: 28-45 yaş arası, en az 5 yıllık antrenörlük deneyimine sahip, faal olarak antrenörlük mesleğini sürdüren 5 antrenörden oluşmaktadır. Veriler, araştırmacının geliştirmiş olduğu yarı yapılandırılmış görüşme formu ile toplanmıştır. Ses kayıt cihazı ile elde edilen veriler önce düz yazıya geçirilmiştir. Araştırma sonucu elde edilen bulgular, betimsel ve içerik analiz yöntemiyle çözümlenmiştir. Çalışmada analiz edilen bulgular neticesinde eskrim antrenörlerine göre eskrim sporcularını psikolojik açıdan etkileyen faktörler; eskrim antrenörlerinin sporcuların performansına etki eden psikolojik faktörlere ilişkin görüşleri ana teması altında, antrenman motivasyonuna ilişskin görüşler, müsabaka esnasındaki faktörlere ilişkin görüşler, sporcunun kişilik özelliklerine ilişkin görüşler, sporcuyu etkileyen zihinsel faktörlere ilişsin görüşler alt temalarında incelenmiştir.

\section{Evaluation of Psychological Factors Affecting Performance of Fencing Players According to Fencing Coaches: Qualitative Study}

\begin{abstract}
This research was designed with the aim of measuring psychological factors affecting the performance of fencing athletes. In the research, case study design from qualitative research methods was used. Sampling method is an easily achievable case sampling from purposive sampling methods. Data were collected with a semi-structured interview form constructed by the researcher. Interview was done with 5 trainers at national team level. The interview was done with voice recorder, data were first written down in plain form. The information written in plain form were then coded by professionals in the area. Descriptive and content analysis methods were used to solve the findings from the research. In terms of findings analyzed in the study, according to the fencing coaches, factors affecting fencing athletes psychologically; under the main theme of the fencing coaches' opinions on the psychological factors affecting the performance of the athletes, the following topics were examined: opinions regarding training motivation, opinions regarding factors during competition, opinions regarding athlete's personality traits, opinions regarding mental factors affecting athletes.

Original Article

Keywords:
Fencing,
Psychological adaptability,
Physical education and sport,

Qualitative
\end{abstract}

\section{GíRiş}

Spor günümüzde tüm dünyayı ilgilendiren bir mesele haline gelmiş kültürel, ekonomik, sosyal, zihinsel, psikolojik, fiziksel bir olgudur. Sporun tüm dünyayı etkileyen bir fenomen haline gelmesi, dev bir ekonomik ortam oluşmasına sebebiyet vermiş bu da beraberinde

\footnotetext{
* Sorumlu Yazar: Naci KALKAN, Arş. Gör.

kalkannaci@hotmail.com
} 
sürekli gelişen ve amansızlaşan mücadeleyi de beraberinde getirmiştir. Spor ortamında hedeflenen başarıya ulaşmada toplam performansın yükseltilmesi önem arz etmektedir. Sportif performans; hedeflenen bir atletik görevin sergilenmesi esnasında başarı için ortaya konulan çabaların bütünü olarak tanımlanabilmektedir (Bayraktar ve Kurtoğlu, 2009). Diğer anlamıyla performans, yarışma veya karşılaşma sırasında göreceli olarak kısa zamanda ve sonucu etkileyen tüm değişkenleriyle bir bütün oluşturmakta ve bu sonuçlar neticesinde değerlendirilmektedir (Atasü ve ark., 2004).

Sporcuların rekabet ortamında var olabilmesi ve ilerleyebilmesi için performansını sürekli olarak yukarıya taşıması gerekmektedir. Spor denince akla ilk olarak fiziksel becerilerin ön plana çıktığı bir durum gelmektedir ancak son yıllarda yapılan çalışmalar mental becerilerin de fiziksel beceriler kadar önemli olduğunu ortaya koymaktadır (Tavacıoğlu, 1999). Sportif performansı en üst düzeye taşımak amacı ile yapılan fiziksel antrenmanların yanı sıra zihinsel becerileri geliştirici mental antrenmanlar da antrenman repertuarlarının içerisinde kendisine yer bulmaktadır (Erkan, 1998). Fiziksel antrenmanların yanı sıra, sportif performansına adına girişilen çabalarda, psikolojik hazırlığın çok dikkate alınmadığı programlarda, sportif performansı olumsuz etkileyen sonuçlar ortaya çıkabilir, bunun neticesinde de başarısız sonuçların alınabilmesi mümkün olabilmektedir (Konter, 2006). Sonuç olarak; psikolojik beceriler de tıpkı fiziksel beceriler gibi antrene edilebilir ve performans yönü artırılabilir. Bunun için de "psikolojik beceri antrenmanlarının da fiziksel antrenmanlar gibi düzenli ve sistematik olarak programlanması ve uygulanmas1 gerekmektedir" (Ercan, 2013).

Eskrim sporu 3 farklı branşta epe, flöre ve kılıç silahlarıyla yapılmaktadır. Eskrim sporunda epe ve flöre silahları dürtüş silahı iken kılıç silahı dürtüş ve vuruş silahıdır. Epe ve flöre branşlarında, $1 \mathrm{~cm}$ çapında puandere ismi verilen ucun rakibe dürtüş amacıyla kullanılması, kılıç branşında ise gövde kısmına dürtüş ve vuruş yapılması gerekliliği düşünüldügünde, eskrim sporcularının müsabaka boyunca fiziksel performansı üst seviyede sergilemesi gerekliliği kadar, dikkat, konsantrasyon, motivasyon gibi psikolojik değişkenleri de koruması ve sergilemesi önemlidir (Roi \& Bianchedi, 2008). Zihinsel açıdan eskrim, birçok stratejinin ardışık biçimde geliştirilmesi ve bu süreç içerisinde sürekli değişen taktiksel hamlelere karşı uygulamaların gerçekleştirilmesini gerektirir. Eskrim sporcularının, yıldız, genç, büyük kategorilerinde pul maçlarının 5 tuş üzerinden 3 dakika sürdüğü, direkt eleme müsabakalarının da 15 tuş üzerinden 3 dakikadan 3 periyot sürdüğü oldukça kısa maç sürelerinde, rakibini hızlıca değerlendirmesi ve buna karşılık taktik ve teknik uyarlamaları yapmaları gerekmektedir. Tüm bunlar göz önüne alındığında, eskrimin zihinsel bir oyun özelliklerini büyük oranda kapsadığını düşünebiliriz. Bu nedenlerle, eskrim sporcularının performansını etkileyen psikolojik etmenlerin değerlendirilmesi, bunların geliştirilmesi ya da sporcuyu olumsuz etkileyebilecek faktörlerin olası etkilerinin engellenmesi sporcunun performansı açısından önem kazanmaktadır. 


\section{YÖNTEM}

\section{Araştırma Modeli}

Araştırmada eskrim antrenörlerinin görüşlerine göre sporcuların performansını etkileyen psikolojik faktörler, nitel araştırma yöntemlerinden durum çalışması yöntemi kullanılarak saptanmaya çalışılmıştır.

\section{Araştırma Grubu}

Araştırmada görüşülen grup, 28-45 yaş arası, en az 5 yıllık antrenörlük deneyimine sahip, faal olarak antrenörlük mesleğini sürdüren 5 antrenörden oluşmaktadır. Örneklem seçiminde, amaçlı örneklem yöntemlerinden kolay ulaşılabilir durum örneklemesine başvurulmuştur. Araştırma grubunu oluşturan 5 eskrim antrenörünün kişisel bilgileri Tablo 1 ve Tablo 2'de sunulmuştur.

\section{Görüşmecilerin Ö̈geçmişleri}

Görüşmeciler, 28-45 yaş arası, en az 5 yıllık antrenörlük deneyimine sahip, faal olarak antrenörlük mesleğini sürdüren 5 antrenörden oluşmaktadır. Örneklem grubu araştırmacıya yakın olması sebebiyle bulunduğu bölgeden seçilmiştir. Tüm antrenörlerin ulusal ve uluslararası tecrübesi bulunmaktadır. Tüm antrenörler en az 2. Kademe antrenörlük belgesine sahiptir ve faal olarak sporcu yetiştirmektedirler.

Tablo 1: Araştırmaya katılan katılımcıların demografik özelliklerine ilişkin bilgiler

\begin{tabular}{llllll}
\hline $\begin{array}{l}\text { Kişi } \\
\text { No }\end{array}$ & Cinsiyet & Yaş & Medeni Durum & Ĕ̆itim Durumu & $\begin{array}{l}\text { Üniversite } \\
\text { Bölümü }\end{array}$ \\
\hline K1 & Erkek & 28 & Bekar & Lisans/Mezun & BESYO \\
K2 & Erkek & 29 & Bekar & Yüksek Lisans/ Mezun & BESYO \\
K3 & Erkek & 38 & Evli & Lise/Mezun & - \\
K4 & Erkek & 45 & Evli & Lisans/Mezun & BESYO \\
K5 & Kadın & 30 & Bekar & Lisans/Mezun & BESYO \\
\hline
\end{tabular}

Tablo 2: Araştırmaya katılan katılımcıların spor branşı özgeçmişi hakkında bilgiler

\begin{tabular}{llllll}
\hline $\begin{array}{l}\text { Kişi } \\
\text { No }\end{array}$ & $\begin{array}{l}\text { Ant. } \\
\text { Derecesi }\end{array}$ & $\begin{array}{l}\text { Başlama } \\
\text { Yılı }\end{array}$ & $\begin{array}{l}\text { Milli } \\
\text { Sporculuk }\end{array}$ & $\begin{array}{l}\text { Milli } \\
\text { Antrenörlük }\end{array}$ & Başarılar \\
\hline K1 & 2. Kademe & 2011 & Var & Var & Çeşitli Türkiye Dereceleri \\
K2 & 2. Kademe & 2010 & Var & Yok & Çeşitli Türkiye Dereceleri \\
K3 & 3. Kademe & 2000 & Yok & Var & Çeşitli Türkiye/Uluslararası Dereceleri \\
K4 & 2. Kademe & 1995 & Var & Yok & Çeşitli Türkiye Dereceleri \\
K5 & 3. Kademe & 2006 & Var & Var & Çeşitli Türkiye Dereceleri \\
\hline
\end{tabular}




\section{Araştırma Yapılan Alan}

Araştırmada yapılan görüşmeler, katılımcıların talepleri doğrultusunda, sessiz ve uygun ortamlarda yapılmıştır. Yapılan tüm görüşmeler antrenörlerin ofislerinde gerçekleştirilmiştir.

\section{Verilerin Toplanması ve Görüşme Formunun Hazırlanması}

Araştırmada veri toplama yöntemi olarak, "görüşme" yaklaşımı ve bu yaklaşımda "görüşme formu yöntemi” kullanılmıştır.

\section{Görüş̧meler}

$\mathrm{Bu}$ araştırmada yapılan yüz yüze görüşmeler, 28-45 yaş arası, en az 5 yıllık antrenörlük deneyimine sahip, faal olarak antrenörlük mesleğini sürdüren 5 kişi ile yüz yüze gerçekleştirilmiştir. Görüşmeler ses kayıt cihazı ile kayıt altına alınmıştır. Elde edilen veriler düz yazıya dönüştürülmüş, ham veriler alanında uzman 3 kişi tarafından kodlanmıştır. Veriler Nvivo 11 Programı ile analiz edilmiştir.

\section{Görüşme Soruları}

1) Size göre, sporcuların performansını etkileyen sosyal faktörler hakkında ne düşünüyorsunuz?

2) Müsabaka sırasında, sporcunun performansını psikolojik yönden etkileyen faktörler hakkında ne düşünüyorsunuz?

3) Antrenman sırasında, sporcunun performansını psikolojik yönden etkileyen faktörler hakkında ne düşünüyorsunuz?

4) Sporcunun kişilik özellikleri psikolojik performansını nasıl etkiler? Sizin bu konuyla ilgili tespitleriniz var $\mathrm{m}$ ?

5) Zihinsel faktörler sporcu performansını sizce nasıl etkiler? Takımınızda böyle bir gözlem yaptınız mı?

\section{Verilerin Analizi}

Araştırmada, verilerin anlaşılır bir biçimde çözümlenmesi, neden sonuç ilişkilerinin irdelenerek birtakım sonuçlara ulaşılması ve bulguların yorumlanması için, nitel analiz yöntemlerinden "betimsel analiz" yöntemi kullanılmıştır. Görüşmeler ses kayıt cihazı ile kayıt altına alınmıştır. Elde edilen veriler düz yazıya dönüştürülmüş, ham veriler alanında uzman 3 kişi tarafından kodlanmıştır. Veriler Nvivo 11 Programı ile analiz edilmiştir.

- Araştırmanın Amacı: Eskrim sporcularının performansını etkileyen psikolojik faktörlerin değerlendirilmesidir.

- Araştırmanın Önemi: Eskrim sporcularının başarı düzeylerini etkileyen psikolojik faktörlerin değerlendirilmesi ile eskrim antrenörlerine ve Türkiye Eskrim Federasyonu'na (TEF) psikolojik etmenlerin sporcu performansina etkilerinin anlatılabilmesi.

- Örneklem Grubu: 28-45 yaş arası, en az 5 yıllık antrenörlük deneyimine sahip, faal olarak antrenörlük mesleğini sürdüren 5 antrenörden oluşmaktadır. 


\section{Geçerlik ve Güvenirlik}

Geçerlik; Araştırmacı araştırma sürecinde gerekli gördüğü takdirde, yeni stratejilere başvurabilir, görüşmeye yeni sorular ekleyebilir, daha önce planlanmayan yeni görüşmeler yapabilir, elde ettiği bilgileri teyit etmek amacıyla farklı veri toplama yöntemleri kullanabilir. Tüm bu özellikler araştırmacının iç geçerlilik konusunda duyarlı olmasını ve gerekirse buna yönelik ek önlemler almasını gerektirmektedir (Yıldırım ve Şimşek, 2005).

İç Geçerlik; $\mathrm{Bu}$ süreç araştırmacının, araştırma sonuçlarına ulaşırken izlediği yolların becerisini ortaya koymaktadir.

- Bulguların tutarlı ve anlamlı olmasına özen gösterilmiştir.

- Bulguların bütünlügüne dikkat edilmiştir.

- Araştırmada bulgular, araştırmacı tarafindan ses kayıt cihazı ile kontrol edilmiş aynı zamanda görüşme esnasında kısa notlar tutmuştur.

Dış Geçerlik; Bu bölümde araştırma süresince dış geçerliğe ait şu konulara dikkat edilmiştir;

- Araştırmacı, araştırmanın yöntemlerini ve aşamalarını açık şekilde tanımlamıştır.

- Araştırmacı, verilerin elde edilmesi, kodlanması, yorumlanması hususlarını açıkça ifade etmiştir.

- Araştırmanın her sürecinde spor psikolojisi ve eskrim alanından uzmanların görüşlerine başvurulmuştur.

Güvenirliği; İnsan davranışlarının değişkenliği ve komplike yapısı, insan davranışını konu edinen bir araştırmanın aynı şekilde tekrarını güçleştirmektedir ancak nitel araştırmalarda güvenirliğe yönelik bazı önlemler vardır. Araştırmacının araştırma sürecinde kendi konumunu açık hale getirmesi, araştırmada veri kaynağı olan bireylerin açık şekilde tanımlanması, araştırma sürecinde oluşan sosyal olayların ve süreçlerin tanımlanması, elde edilen verilerin analizinde kullanılan kavramsal çerçevenin ve varsayımların tanımlanması, veri toplama ve analiz yöntemlerinin detaylı olarak açıklanması, bu önlemler arasındadır (Yıldırım ve Şimşek, 2008).

- Araştırmada katılımcılara sorulan sorular net bir biçimde ifade edilmiştir.

- Araştırma sürecinde kullanılan yöntem ve aşamalar ifade edilmiştir.

- Araştırma kapsamında elde edilen veriler gerektiğinde değerlendirilmek üzere saklı tutulmuştur.

- Görüşme yapılan kişiler K koduyla tanımlanmıştır.

- Araştırmada alanında uzman iki araştırmacı kodlamaları gerçekleştirmiştir. 


\section{BULGULAR}

\section{Eskrim Antrenörlerine Göre Sporcuların Performansını Etkileyen Psikolojik Faktörler}

Çalışmada elde edilen veriler 1şı̆̆ında eskrim sporcularının performansını etkileyen psikolojik faktörler ana teması altında toplanmıştır. Bu faktörler, antrenman motivasyonuna ilişkin görüşler, müsabaka esnasındaki faktörlere ilişkin görüşler, sporcunun kişilik özelliklerine göre ilişkin görüşler ve sporcuyu etkileyen zihinsel faktörlere ilişkin görüşler alt temalarında ele alınmıştır.

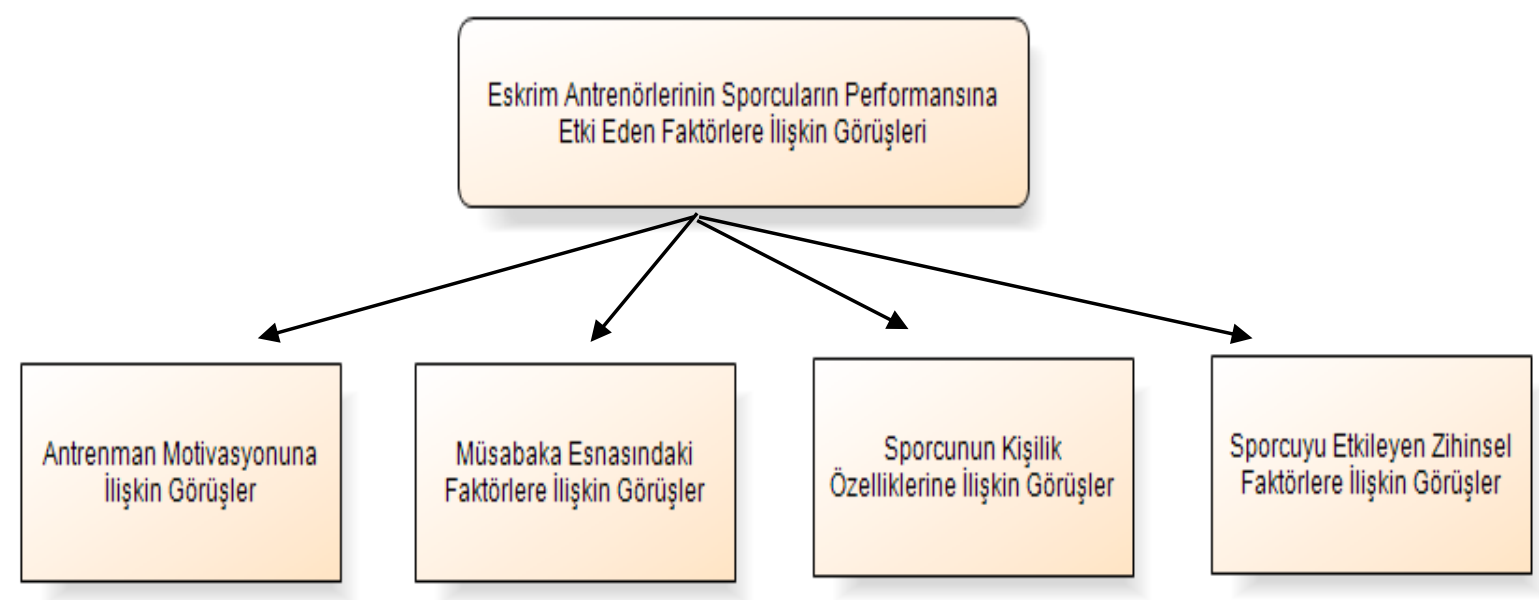

Şekil 1: Eskrim antrenörlerine göre sporcuların performansını etkileyen psikolojik faktörler

\section{Antrenman Motivasyonuna İlişkin Görüşlere Dair Bulgular}

Antrenman motivasyonuna ilişkin görüşlere dair ana tema bulgularında görüşmeciler, antrenör, takım arkadaşları, aile, antrenman yeri ve antrenman metotları alt temaları hakkında görüş bildirmişlerdir.

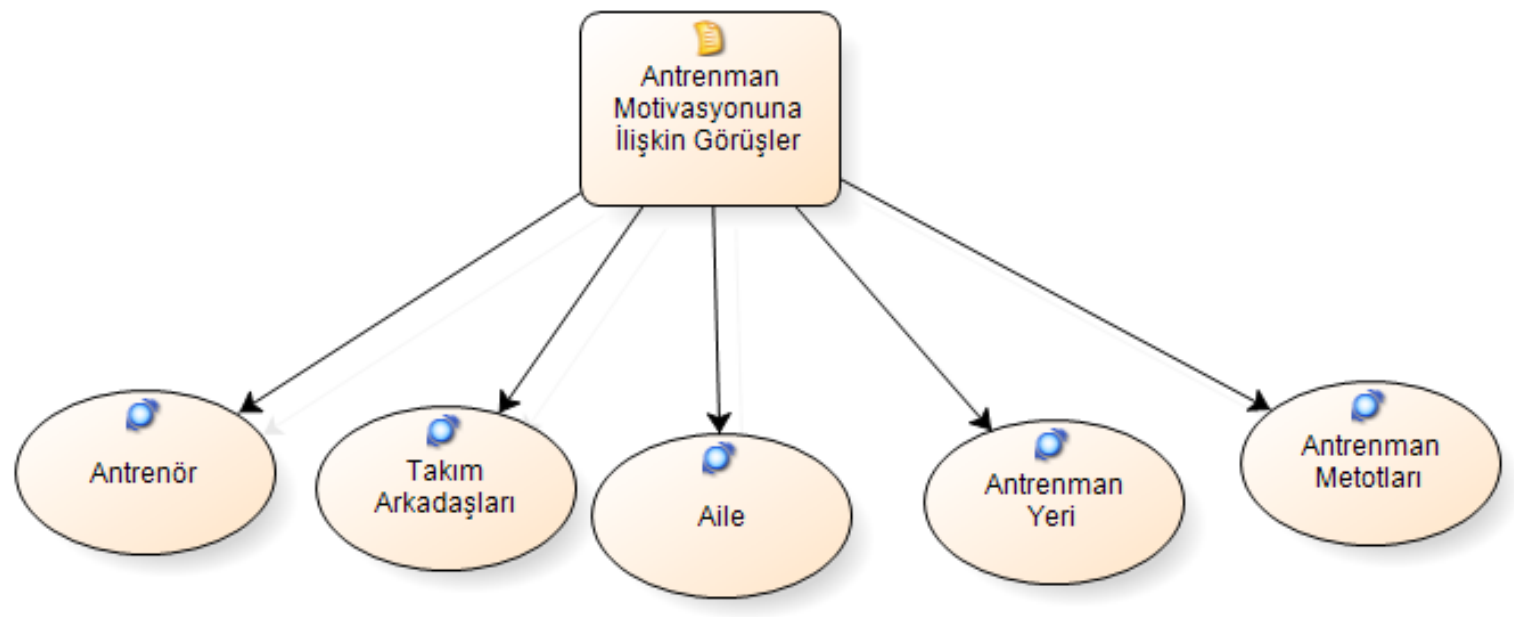

Şekil 2: Antrenman motivasyonuna ilişkin görüşlere dair bulgular 


\section{Antrenman Yeri}

K1: Farklı gruplar aynı anda çalışırsa çok büyük sıkıntı çünkü zaten minimum bir branşta 10 kişi var bu salonda demek 30 kişi ve her kafadan başka ses demek her antrenörü farklı çalışma sistemi demek hedef bulamamak demek ya da çalışma alanın daralması demek. Kalabalık faktörü etkiliyor. K3: Antrenman sahası bizde çok çok önemli, küçük salonlar, kalabalık mevcutlar, işimizi çok zorlaştırmakta, sporcuların hedef çalışmak için bile sıra beklediği durumlarda, onların \%80'lerde antrenman yapmasinı beklemek hayalcilik oluyor.

\section{Antrenman Metotları}

K2: Kesinlikle antrenman öncesi çalışmalar eskrimde yapılmıyor, bizde klasik bir uygulama vardır, eskrimci gelir ayak hareketi çalışı, eline silahı verirsin, ya ders verirsin ya da komba dediğimiz antrenman maçını yaparlar.

K:4 Gönül ister ki; yıllık plan yapılsa, antrenman gün ve saatleri belli olsa, belli bir sürede, birkaç aylık bir süreçte çocukların koşu yapması, yüzmesi, tabii ki belli kontroller altında ă̆ırlık çalışması ki çünkü bacak ve koldan önemli bir şey yok.

\section{Antrenör}

K1: Eskrim bireysel bir spordur ve piste çıktı̆̆ınızda hakem ve rakipten başka kimse yoktur, arkanızda sadece bir antrenör bulunabilmekte, o antrenörün jestlerinden mimiklerine, verdiği taktiklere kadar sporcunun performansına inanılmaz büyük etkileri var.

K5: Antrenör çocuğu sakinleştirecek, çocuk hata yapabilir. Önemli olan ikinci antrenmanda bu hatayı tekrar etmemesi o yüzden psikolojik olarak antrenöre iş düşüyor.

\section{Aile}

K3: Salon içerisinde veli kesinlikle olmamall, bu şart...

K4: Aile. Ĕger aile izliyorsa ve sporcu bir hareketi yanlış yaptrysa eve ya da antrenman çıkışında eve gittiklerinde ya da antrenmandan çıktıklarında veliler hemen onu öyle yapmamalıydın yanlış yaptın gibi söylemlerle çocukları demoralize ediyor. Aslında bizde en büyük sıkıntı ailenin işe karışması...

\section{Takım Arkadașları}

K2: Eskrimde takımdaşlık biraz uzak bir kavram, partner olarak çalıştığınız bir sporcu, yarın size bir final müsabakasında, milli takım seçmesinde direkt olarak rakip olabiliyor.

K3: Sporcular arasinda iyi olanlar, daha az iyi olanlar ve yeniler olabiliyor. Alaycl konuşmalar olabiliyor, küçümsemeler olabiliyor, bu da yeni başlayan sporcular bundan etkilenebiliyor, tecrübeliler uyarmamıza rağmen bu alaya devam edebiliyor 


\section{Müsabaka Esnasındaki Faktörlere İlişkin Bulgular}

Müsabaka esnasındaki faktörlere ilişkin görüşlere dair ana tema bulgularında görüşmeciler, müsabakalardaki bekleme süreleri, hakem, antrenör, rakip sporcular, seyirci alt temaları hakkında görüş bildirmişlerdir.

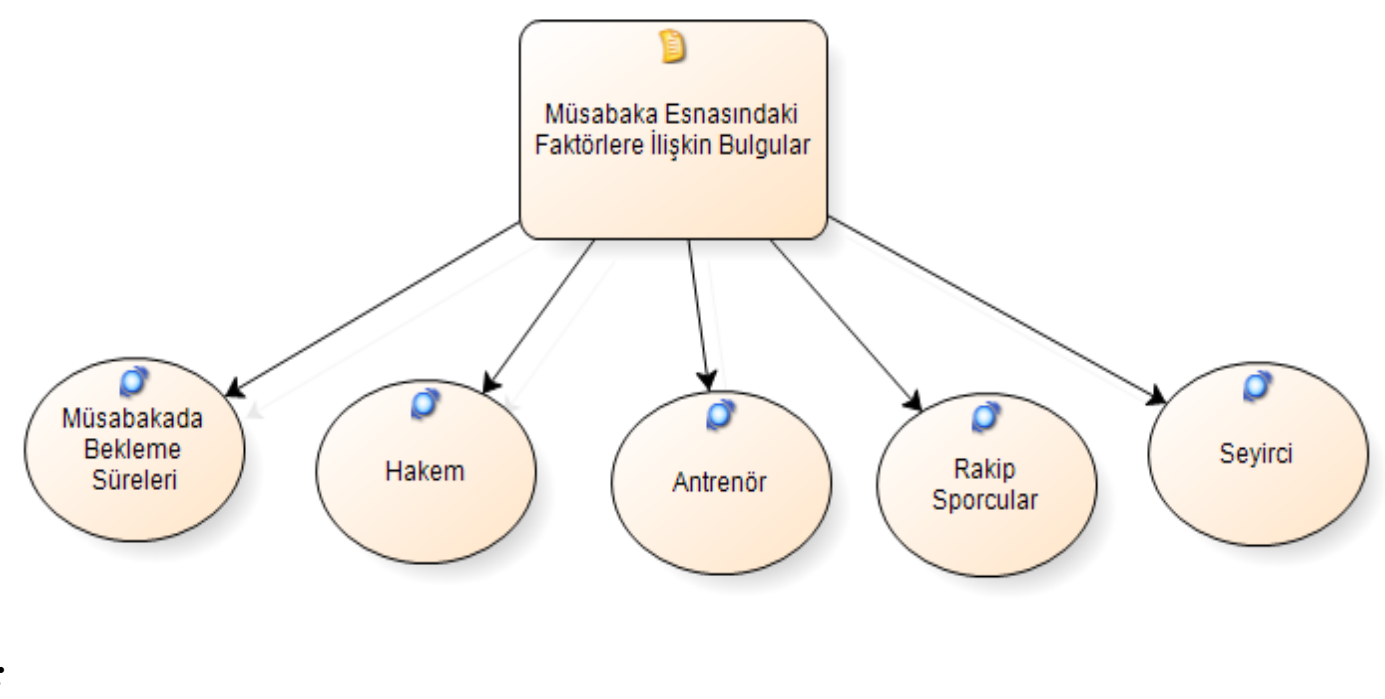

Şekil 3: Müsabaka esnasındaki faktörlere ilişkin bulgular

K2: Seyircilerin müsabakaya etkisi var, seyircilerin bağırışları, yeri geldiğinde itirazları, hakemlerin bundan etkilenmesi olabiliyor, bu da sporcuyu etkiliyor. Seyircinin tepkileri hakeme kendini sorgulatabiliyor.

K3: Müsabaka salonunun atmosferine de 'seyirciyi bir motivasyon aracı olarak gören sporcularda etkili oluyor' kimi sporcu bunu bir baski unsuru olarak görürken kimi sporcular da seyircilere ve çevreye kendini ispat etmek için ekstra efor sarfediyorlar.

\section{Hakem}

K1: Ikkinci faktör hakem faktörü yanlış bir karar verebilir verdiğinde antrenörün çocuğu sakinleştirmesi lazım yani olabilir hata yapılabilir ama bu hareketi değiştirebilirsin diyebilir.

K5: Hakemlerin maçta almış olduğu kararlar da sporcuyu etkileyen bir faktördür bana göre, müsabaka içerisinde hakem yanlış bir karar verebilir ve sporcu o kararın etkisinde kalabilir. Rakiple maç yaparken rakibi kural harici bir sayı aldığında hakem bunu göremeyebiliyor ve sporcu bunu gördüğ̈̈nde çöküyor, 'tuş benimdi, hakem bana vermedi, bu yüzden yenildim' gibi söylemlere dönüşebiliyor. 


\section{Müsabakada Bekleme Süreleri}

K3: Günümüz şartlarında müsabakalar artık değişti. Sabah grubu, öğlen grubu, öğleden sonra grubu gibi çocuk belli bir süreyi bekleyerek yani uyuyarak geçiriyor. Bu performansı etkileyen en büyük fatörlerden biri.

K4: Eskrim 6 branşı olan kızlı erkekli oynanan bir spor, katılım çok yoğun oluyor, bir salonda aynı günde 3 branş oynanıyor, müsabakalar arasında çok uzun bekleme süreleri olabiliyor, bu da sporcuların dă̆llmasına sebep olabiliyor

\section{Rakip Sporcular}

K5: Rakip bir sporcunun sırtında yazan TUR ibaresi onunla karşılacak rakibini baskı altına alabiliyor. 'Aa bu milli takım sporcusu, kesinlikle benden iyidir' diyerek, daha maç başlamadan maç kaybedilebiliyor.

\section{Antrenör}

K2: Hoca olarak bizim de hatalarımı olabiliyor, bir hareket üzerinde inatlaşabiliyoruz, yapamadıkları zaman sinirlenip yüksek sesle tepki verebiliyoruz.

K4: Bizim sporda da şöyle bir durum var, aynı anda birkaç sporcu da maç yapabiliyor, 3-4 dakika bir sporcunuzun yanındayken birkaç dakika başka birinin yanına gidebiliyorsun, öyle sporcular var ki, antrenörü yanında olmadan maç bile oynayamaz veya tam tersi antrenörü yanında olmaması gerekli veya başka bir sevdiği, iyi eskrimci olan abisinin yanında olmasını ister.

\section{Sporcunun Kişilik Özelliklerine İlişkin Görüşlere Dair Bulgular}

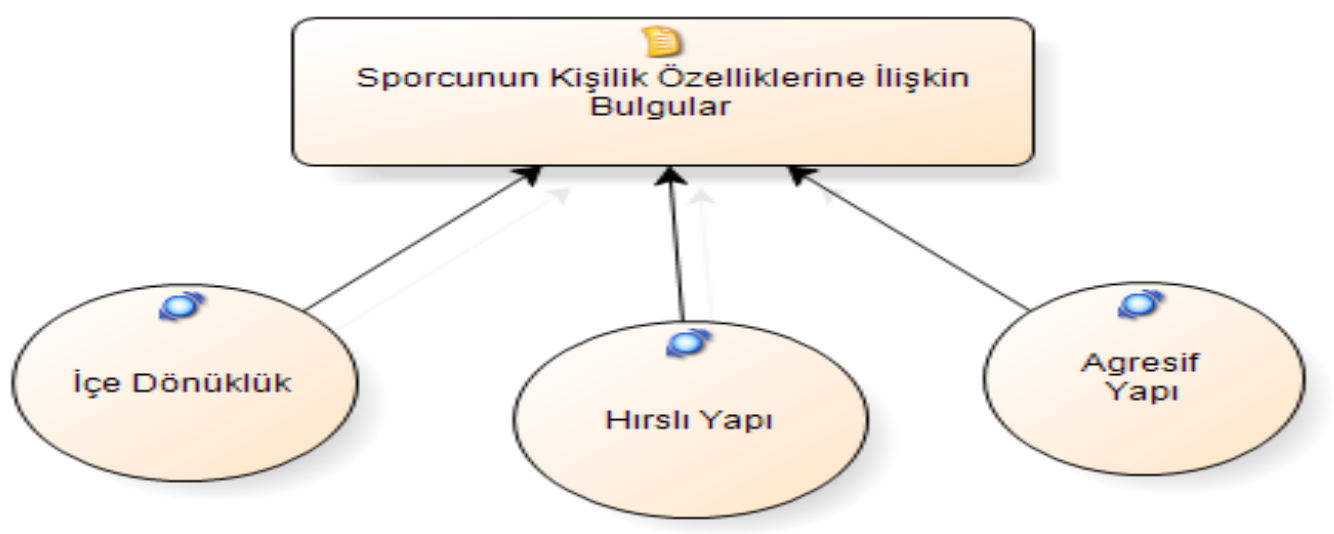

Şekil 4: Sporcunun kişilik özelliklerine ilişkin görüşlere dair bulgular

Sporcunun kişilik özelliklerine ilişkin görüşlere dair ana tema bulgularında görüşmeciler, içe dönüklük, hırslı yapı, agresif yapı alt temaları hakkında görüş bildirmişlerdir. 


\section{Hirslı Yapı}

K1: Hırsla beraber psikoloji eksi tarafa dönebilir, fazlası çok tehlikelidir.

K5: Çok hırslı bir sporcunun çok başarısı olduğunu görebiliyorsunuz veya tamamen boş gözle bakan ciddiye almayan birinin de başarılı olmasını ama başarılı derken, kısa zamanı kapsayan bir başarı çünkü zaten kendini vermediğin sürece bu olay bitmiştir.

\section{Agresif Yapı}

K3: Mesela çok sinirli bir sporcu özellikle eskrimde çok tehlikeli bir şeydir, eskrim çünkü teknik üzerine kurulu bir spordur. Sinirli olan sporcu tekniğini kaybeder, koordinasyonunu kaybeder, silaha hakimiyet kuramaz

K4: Hirçınlık aslında iyi, ama onu ayarlayabilrsek iyi. Yan frenlemesi çok iyi frenleyemezse zaten direkt hataya meyilli oluyor.

\section{İ̧e Dönüklük}

K1: İçe dönükler çok problem yaşıyor, atak yapıp tuş yiyor, bir daha atak yap dediğin zaman atak yapmıyor çünkü biliyor tuş yiyeceğini ve korkuyor bu sefer geri kaçmaya başlıyor hakemin hazır başla komutundan sonra direkt geri atağa başlıyor, kontratak yapmaya başliyor.

K4: Çok zaylf bir çocuk psikolojik olarak zaylf bir çocuk işte kaştan, gözden ya da rakibin bağırmasından etkileniyor, rakibin bağırması da onu oyundan düşürüyor.

\section{Sporcuyu Etkileyen Zihinsel Faktörlere İlişkin Görüşlere Dair Bulgular}

Sporcuları etkileyen zihinsel faktörlere ilişkin görüşlere dair ana tema bulgularında görüşmeciler, karar verme yetisi, konsantrasyon, dikkat alt temaları hakkında görüş bildirmişlerdir.

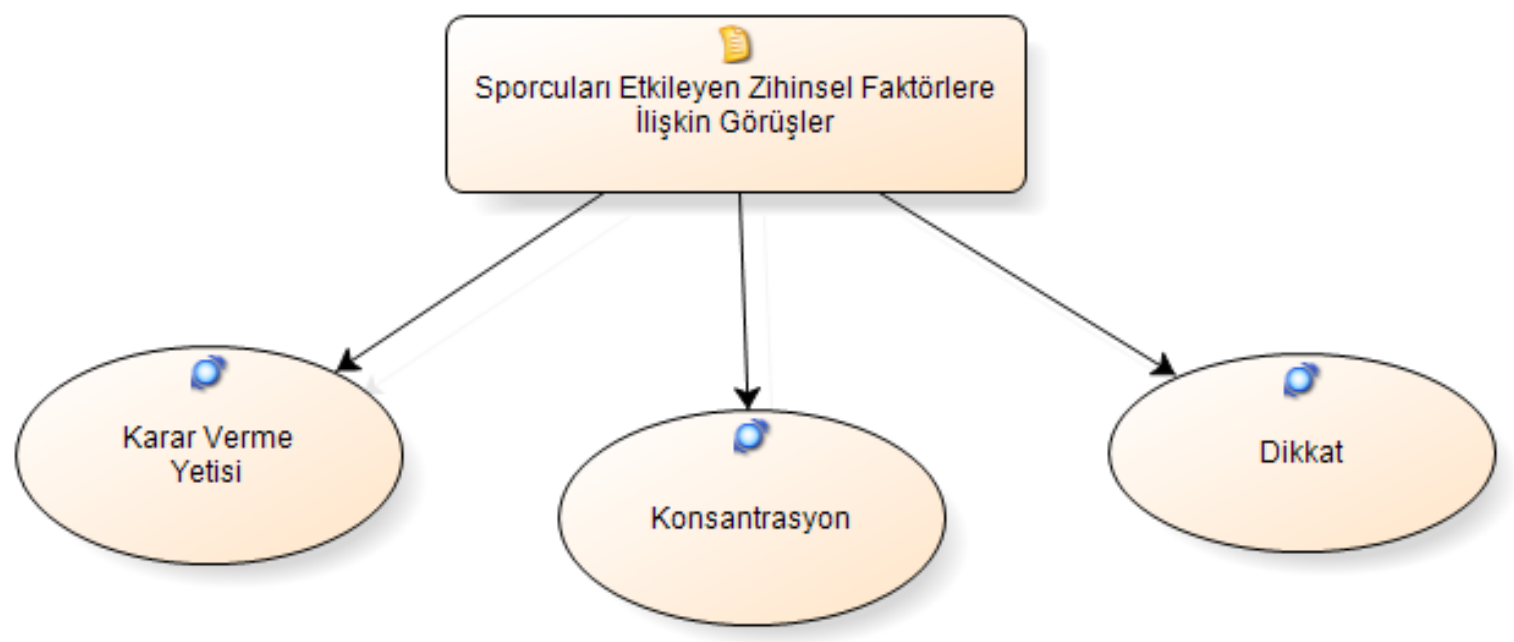

Şekil 5. Sporcuyu etkileyen zihinsel faktörlere ilişkin görüşlere dair bulgular 


\section{Konsantrasyon}

K1: Odaklanmak yani rakibe ne yapacă̆ını bilmek ertesi gün piste çıktı̆̆ında ilk atağının ne olacağını düşündürmek bu odaklanmak yani atakla mı başlayacak yoksa atak esnasında farklı bir hareket mi yapacak.

K5: Öncelikle çocuğun hayatında, müsabakası olsun olmasın, o günlerde kafasının rahat olması gerekiyor, okulda bir düzen olması gerekiyor, yaşadı̆̆ her şeyin dışarıda kalması gerekiyor.

\section{Dikkat}

K3: Dikkat, net bir şekilde olmall. Eskrimin net şeyleri vardır, hep deriz ya, 'eskrim satrancın ayakta oynanır' diye, ben buna hep gülerim esasında ama... Eskrim kombine bir spor, dikkat şart.

K4: Bunu çocuklar sinavlarda da yaşlyor 2+2'ye 3 diyor, nedir bu dikkat eksikliği, eskrimde çok dikkatli olacaksın, yani ummadı̆̆ın bir sporcu, 2 günlük bir eskrimci 30 yıllık bir eskrimciyi 5-0 yenebiliyor, bu küçümsemedir, dikkatsizliktir.

\section{Karar verme yetisi}

K1: Tamam bacak önemli, kol önemli, zamanlama önemli ama bunun yanında 'beyin' her şey beyin dediğim gibi, ani düşünce ve bunun yanına şunu koyabiliriz, her rakibe karşı farklı düşünce.

K2: Hizlı karar verebilme yetisi bence motorik özelliklerden daha önemli, eskrim zekasinı yansitmak bence hepsinden önemli.

\section{TARTIŞMA VE SONUÇ}

Gould ve arkadaşları (1999), sporcuların olimpiyatlardaki performansını etkileyen faktörleri araştırmıştır. Çalışmada sportif performansı etkileyen fiziksel, sosyal ve çevresel faktörlerin yanı sıra zihinsel beceri ve strateji kurma becerilerinin performansı doğrudan etkileyen faktörler olduğu sonucuna ulaşılmıştır. Eskrim antrenörlerinin görüşlerine göre tasarlanmış bu çalışmada elde edilen verilerden ulaşılan sonuçlarda, sporcuların performansını etkileyen zihinsel faktörlerin önemine dair çıktılara ulaşılmıştır. Bu bağlamda, dikkat, konsantrasyon ve karar alma sürecinin sportif performansa etki ettiğine yönelik sonuçların benzerlik gösterdiği söylenebilir.

Bali (2015), spor performansını etkileyen psikolojik faktörler üzerine yaptığı çalışmasında, zihinsel hazırlığın Olimpiyat sıralamasında en önemli istatistiksel bağlantı olduğu düşündüğünü belirtmiştir. Spor performansının psikolojik yönü parametrelerinde spor psikolojisi konulu uluslararası konferans ve seminerlerde gündeme getirilen, tartışılan ve tartışılan yüzde 70'ten fazla sorunun, duyguların türüne göre endişe ve saldırganlık ile ilgili olduğunu belirtilmektedir. Stres, kayg1, gerginlik ve saldırganlığ1 yönetmek veya kontrol altına alınması gerektiğini vurgulamıştır. Bali'nin çalışmasındaki, stres, kaygı, gerginlik ve 
saldırganlığı yönetmenin performansı biçimlendirmedeki önemli rolü, eskrim sporcularının psikolojik performansını gözeten bu çalışmada da ön plana çıkmaktadır. Eskrimin bireysel bir spor olması, kısa süre içerisinde müsabakaların sonuçlanması, ince motor becerinin sürekli olarak kontrolü gerekliliği, müsabaka esnasında sporcuları etkileyen psikolojik faktörler temasıyla örtüşmektedir. Eskrim sporcularının müsabaka içerisinde, psikolojik performansını biçimlendiren faktörler antrenörler tarafından, müsabakalardaki bekleme süreleri, hakem, antrenör, rakip sporcular, seyirci olarak belirtilmiştir, tüm bunların sporcular üzerinde bir stresör olduğu, bu stresörlerin yönetme becerisinin Bali'nin çalışması göz önüne alındığında sportif performansı şekillendiren faktörler olarak ele alınabileceğini göstermektedir.

Onağ ve ark., (2013) yaptıkları "Futbol antrenörlerinin görüşlerine göre, takım başarısını etkileyen faktörler: Nitel bir araştırma" isimli çalışmada, antrenörlerin özellikleri, kulüp yapısı, sporcular, teknik ekip, tesis, taraftar, basın gibi unsurların da sportif başarı üzerinde etkisi olduğu sonucuna ulaşmışlardır. Çalışmada sportif performansını oluşturmada etkisi olduğu düşünülen psikolojik faktörler arasında antrenman motivasyonuna ilişkin görüşler temasında belirtilen, antrenör, tesis, antrenman metotları gibi faktörler iki çalışma arasındaki paralleliğe işaret ettiği söylenebilir.

Marcora'nın (2009) yapmış olduğu bir çalışmada ise insanlardaki zihinsel yorgunluğun fiziksel aktiviteyi etkilediğini belirtmiştir. Adeyyeye (2013)'de çalışmasında motivasyonel değişkenlerin sportif performansı belirleyen önemli bir faktör olduğunu ifade etmiştir. Zihinsel becerilerin önemli olduğu eskrim sporunda, fiziksel performansın devamlılı̆̆ının zihinsel becerilerin antrene olmasıyla ilişkili olduğu söylenebilir.

Pensgaard (2002) çalışmasında küçük yaşta spora başlayan sporcuların, başarıya ve hedefe yönelik olarak yarışmacı biçimde motive edilmesinin, sporcuların kaygı durumlarında değişiklilikler yarattığı sonucuna ulaşmış bunun da müsebbibi olarak antrenörlerin yönlendirmelerini göstermiştir. Çalışmada ulaşılan antrenörün sporcu performansı üzerindeki etkisinin önemine dair bu sonuçlar, çalışmamızda antrenörler tarafından ifade edilen psikolojik performans üzerindeki antrenörün etkisi ve önemine dair bulgular ile parallellik gösterdiği söylenebilir.

Cox (2012) çalışmasında, elit sporcularda bulunması gereken özellikleri, içsel motivasyon, kendini denetleyebilme, imgeleme yapabilme, stresle başa çıkabilme yeteneği, başarı ve başarısızlığı yönetebilme, hedef koyabilme, zihinsel açıdan dayanıklı olma, uygun kişilik özellikleri, güven ve motivasyonu sağlama adına kendini telkin edebilme, duygu ve uyarılmışlık kontrolü, tam konsantrasyonu sağlayabilme olarak tespit etmiştir. Çalışmamızda antrenörlerin görüşleri neticesinde elde edilen bulgularda da bunlara benzerlik gösteren ifadelere rastlanmaktadır. Oluşan alt temalarda, kişilik yapısının etkisi, konsantrasyon, dikkat ve karar verme becerilerinin önemine dair bulgular Cox'un tespitlerini destekler nitelikte olduğu söylenebilir. 
Sonuç olarak;

- Antrenörlerin görüşleri neticesinde sporcuların performansını etkileyen faktörlerde, antrenman motivasyonu, müsabaka esnasındaki psikolojik durum, sporcunun kişilik özellikleri ve zihinsel becerileri önemli olduğu söylenebilir.

- Sporcuların başarı düzeylerinin artmasında psikolojik faktörler ile başa çıkma becerilerinin önemli olduğu söylenebilir.

- Antrenman mekanlarının düzenlenmesinde sporcuları psikolojik açıdan etkileyebilecek tüm faktörlerin göz önüne alınması gerektiği ve bu faktörlerin ekarte edilmediği durumlarda antrenman performansında düşüş yaşanabilmesinin mümkün olduğu ifade edilebilir.

- Müsabaka esnasında sporcuların başarı düzeylerini etkileyen bir takım psikolojik faktörler olabilmektedir. Eskrim müsabakalarının programının sporcuların fiziksel ve psikolojik performansına etki eden bir faktör olduğu söylenebilir.

- Sporcuların zihinsel becerilerin eskrim başarı düzeyine doğrudan etkisinin olduğu ifade edilebilir.

- Eskrim hakemlerinin kararlarının sporcuların psikolojik performansını etkilediği söylenebilir.

- Eskrim antrenörlerinin antrenman ve müsabaka sürecinde sporcuyu psikolojik açıdan etkileyen bir faktör olduğu düşünülebilir.

\section{ÖNERİLER}

- Eskrim antrenörlerinin psikolojik antrenmanlar hakkında bilgilendirilmesi gereklidir.

- Federasyon ve kulüplerin sporcuların performansını yükseltmek amacıyla mentör desteği sağlaması düşünülebilir.

- Antrenman salonlarının daha sağlıklı yapılara kavuşturulmaları önem arz etmektedir.

- Eskrim hakemlerinin özellikle küçük yaş müsabakalarında daha dikkatli olması sağlanmalıdır.

- Sporcu velilerinin müsabaka alanlarında ve antrenman alanlarında çalışmaları aksatıcı müdahalelerine yönelik salon düzenlemeleri titizlikle yapılmalıdır.

- Sporcuların etkileşim halinde olduğu diğer sporcular ile ilişkilerine yönelik çeşitli aktiviteler düzenlenerek, sporun birleştirici unsurunun ön plana çıkması sağlanabilir. 
Kalkan, N., ve Zekioğlu, A. (2017). Eskrim sporcularının performansını etkileyen psikolojik faktörlerin değerlendirilmesi: Nitel çalışma. Ulusal Spor Bilimleri Dergisi, 1(1), 29-42.

\section{KAYNAKLAR}

Adeyeye, F. M., Vipene, J. B. \& Asak, D. A. (2013). The Impact of motivation on athletic achievement: A case study of The 18th National Sports Festival. Academic Research International, Vol. 4 No. 5.

Atasü, T., ve Yücesir, İ. (2004). Doping ve futbolda performans artırma yöntemleri. İstanbul: TFF yaynları.

Bali, A. (2015). Psychological factors affecting sports performance. International Journal of Physical Education, Sports and Health, 1(6): 92-95.

Bayraktar, B. ve Kurtoğlu, M. (2009). Sporda performans ve performans artırma yöntemleri. Klinik Gelişim, 22 (1), 16-24.

Cox, R.H. (2012). Psychological skills training. In Sport Psychology. Concepts and Applications. 7th ed. NY New York: McGraw-Hill.

Ercan, H.Y. (2013). Spor ve egzersiz psikolojisi. 2. Bask1. Ankara: Nobel.

Erkan, U. (1998). Sporcular için zihinsel antrenör rehberi. Ankara: Bagırgan.

Gould, D., Guinan, D., Greenleaf, C., Medbery, R. \& Peterson, K. (1999). Factors affecting olympic performance: perceptions of athletes and coaches from more and less successful teams. The Sport Psychologist. Volume 13, Issue 4.

Konter, E. (2006). Spor psikolojisi el kitabı (s,84). Ankara: Nobel.

Marcora, S., M., Staiano, W. \& Manning, V. (2009). Mental fatigue impairs physical performance in humans. Journal of Applied Physiology. Vol. 106, no. 3, 857-864.

Onağ, G. Z., Güzel, P., ve Özbey, S. (2013). Futbol antrenörlerinin görüşlerine göre, takım başarısını etkileyen faktörler: Nitel bir araştırma. Pamukkale Journal of Sport Sciences, 4(2): 125-145.

Pensgaard, A.M., Roberts, G.C. (2002). Elite athletes' experiences of the motivational climate: the coach matters. Scand J Med Sci Sports, 12:54-59.

Roi, G. S., \& Bianchedi, D. (2008). The science of fencing. Sports Medicine, 38(6), 465-481.

Şimşek, H. ve Yıldırım, A. (2003). Sosyal bilimlerde nitel araştırma yöntemleri. Ankara: Seçkin.

Tavacıŏlu, L. (1999). Spor psikolojisi-bilişsel değerlendirmeler. Ankara: Bağırgan. 